\begin{tabular}{lr}
\hline Jurnal Abdimas llmiah & JURNAL ABDIMAS ILMIAH CITRA BAKTI \\
Citra Bakti & Volume 2, Nomor 2, November 2021 \\
$(\mathrm{JAICB})$ & \\
\hline
\end{tabular}

\title{
PENDAMPINGAN MENGELOLA PEMBELAJARAN DARING BAGI GURU-GURU DI CITRA BAKTI SCHOOL
}

\author{
Konstantinus Dua Dhiu'), Dek Ngurah Laba Laksana2), \\ Maria Desidaria Noge ${ }^{3)}$ \\ 1)Program Studi PG-PAUD, 2,3)Program Studi PG-PAUD \\ STKIP Citra Bakti \\ ${ }^{1)}$ duakonstantinus082@gmail.com, ${ }^{2}$ labalaksana@citrabakti.ac.id, ${ }^{3)}$ ennynoge@gmail.com
}

\section{Histori artikel}

Received:

21 November 2021

Accepted:

26 November 2021

Published:

30 November 2021

\begin{abstract}
Abstrak
Tujuan dari pengabdian kepada masyarakat ini adalah meningkatkan kompetensi guru dalam mengelola pembelajaran LMS dan meningkatkan kompetensi guru dalam mebuat konten pembelajaran berbentuk multimedia interaktif. Pentingnya pendampingan ini diharapkan agar para guru di Citra Bakti Schoo/ dapat mendesain media pembelajaran sebagai inovasi dengan memanfaatkan media daring (online). Citra Bakti School yang terdiri atas PAUD Terpadu Citra Bakti, SD Citra Bakti, SMP Citra Bakti dan SMA Citra Bakti juga melakukan pembelajaran secara daring maka diperlukan pendampingan pelaksanaan pembelajaran daring tersebut. Dosen yang mempunyai kewajiaban Tri Dharma Perguruan Tinggi yang salah satunya adalah pengabdian kepada masyarakat dapat berperan serta dalam pendampingan pembelajaran daring tersebut. Pendampingan dilaksanakan dengan melakukan sosialisasi dan pelatihan dan dilanjutkan dengan pendampingan pada pelaksanaan pembelajaran daring. Media LMS yang digunakan adalah Google Classroom, dan pembuatan Video pembelajaran yang di upload di Youtube. Hasil pengabdian masyarakat ini adalah para guru sudah mempunyai kelas online dan dapat melakukan pengelolaan kelas online dan pengasuhan kelas secara daring.
\end{abstract}

Kata-kata Kunci: pendampingan pembelajaran online, guru-guru citra bakti school 
Abstract. The purpose of this community service was to improve teacher competence in managing LMS learning and increasing teacher competence in creating interactive multimedia learning content. The importance of this assistance was expected so that teachers at Citra Bakti School can design learning media as an innovation by utilizing online media. Citra Bakti School, which consists of Citra Bakti Integrated PAUD, Citra Bakti Elementary School, Citra Bakti Junior High School and Citra Bakti Senior High School, also conducts online learning, so this assistance is needed in the implementation of online learning. Lecturers who have the responsibility of the Tri Dharma Perguruan Tinggi which one of them is community service can participate in this online learning assistance. Assistance is carried out by conducting socialization and training and continued with assistance in the implementation of online learning. The LMS media used is Google Classroom, and the creation of learning videos uploaded on Youtube. The result of this community service is that teachers already have online classes and can manage online classes and online classroom parenting.

Keywords: online learning assistance, teachers of citra bakti school

\section{PENDAHULUAN}

Menyikapi kondisi bangsa Indonesia sekarang ini yang tampak tidak siap menghadapi perubahan dan tuntutan kondisi masyarakat, seperti revolusi industry 4.0, penggunaan teknologi internet yang begitu masih (big data, internet of things/loT, dll), merdeka belajar, juga mewabahnya pademi covid 19 di seluruh dunia, termasuk Indonesia (Istyarini, dkk., 2021). Wabah virus corona tentu saja mempengaruhi berbagai aspek kehidupan, tak terkecuali pendidikan. Hal ini sesuai dengan edaran surat edaran Kemendikbud Nomor 2 Tahun 2020 tentang Pencegahan dan Penanganan Covid-19 di lingkungan Kemendikbud dan surat edaran Kemendikbud Nomor 3 Tahun 2020 tentang Pencegahan Covid-19 pada Satuan Pendidikan yang berisi panduan langkah-langkah mencegah berkembangnya penyebaran Covid-19 di lingkungan satuan pendidikan. Adapun surat edaran Mendikbud No 4 Tahun 2020 Tentang Pelaksanaan Kebijakan Pendidikan dalam Masa Darurat Penyebaran Corona Virus Disease (Covid-19) dimana dinyatakan bahwa proses belajar dari rumah melalui pembelajaran daring/jarak jauh. Lewat surat edaran tersebut, Kemendikbud mengeluarkan 18 poin imbauan (protokol) kepada para satuan pendidikan di seluruh Indonesia (Pancawati, 2020). Aktivitas pembelajaran semua jenjang pendidikan di Indonesia dilakukan dari rumah. Mempertimbangkan efektivitas, keamanan dan kenyamanan, metode pembelajaran online secara penuh menjadi pilihan di tengah pandemi yang diharus pembatasan sosial.

Menurut Veronika (Vol.54, No.1: 2021), "The success of online learning was highly dependent on several integrated components, such as students, educators, learning resources, and the technology used' bahwa kesuksesan dalam pembelajaran online bergantung pada beberapa komponen yang terintegrasi seperti, siswa, pendidik, sumber dan bahan pembelajaran dan juga teknologi yang dipakai. Pengembangan kompetensi pekerja pada tingkat pendidikan dan pelatihan adalah isu utama bagi pembangunan ekonomi yang pada gilirannya merupakan prasyarat utama untuk pengembangan masyarakat yang berkelanjutan (Lawe, Y.U., dkk. 2020). 
Oleh karena itu, perlu dikembangkan LMS yang baik dan berkualitas untuk menunjang dan memaksimalkan proses pembelajaran online. Kementerian Pendidikan dan Kebudayaan pun memperpanjang masa belajar dari rumah karena situasi yang belum kondusif. Dengan mempertimbangkan efektivitas, keamanan, dan kenyamanan, pembelajaran melalui e-learning dipilih hampir di seluruh jenjang pendidikan di Indonesia.

E-learning merupakan sebuah sistem maupun konsep pendidikan yang memanfaatkan teknologi informasi dalam proses belajar pembelajaran. Ada beberapa media pembelajaran online yang dapat digunakan dalam proses pembelajaran antara lain: google classroom, zoom, video pembelajaran, video conference, dan platform lainnya. Menurut Unik (Vol.2, No.2: 2020) mengatakan bahwa Google Classroom digunakan oleh setiap orang dari ruang lingkup/ jenjang pendidikan yang berbeda-beda baik dari tingkat SD, SMP, SMA/SMK maupun Perguruan Tinggi. Sedangkan Zoom merupakan aplikasi komunikasi dengan menggunakan video sehingga pada saat digunakan untuk proses pembelajaran maka kita akan merasa bahwa kita sedang tatap muka secara langsung karena kita mampu melihat orang yang jauh dengan menyalakan camera yang kita miliki didalam menggunakan platform zoom ini (Astini, 2020). Di sisi lain, Junita (Vol.IX, No.2: 2020) juga mengatakan bahwa Zoom dapat dikategorikan sebagai media pembelajaran online yang dapat diartikan sebagai suatu jenis belajar mengajar yang memungkinkan tersampaikannya bahan ajar ke siswa dengan menggunakan media Internet. Media pembelajaran online sebagai sebuah alternatif pembelajaran yang berbasis elektronik memberikan banyak manfaat terutama terhadap proses pendidikan yang dilakukan dengan jarak jauh. Pemanfaatan video conference pada pembelajaran jarak jauh akan sangat membantu siswa dan siswi dalam belajar karena pendidik dapat berinteraksi walaupun ditempat yang berbeda. Untuk merangsang semua aspek perkembangan pada siswa tidak lepas dari media pembelajaran, hal ini dikarenakan mahasiswa belajar dilakukan menggunakan media pembelajaran yang nyata, dan dengan media pembelajaran ini mahasiswa dapat berjalan secara efektif (Firman: 2020). Dosen dan guru dalam memanfaatkan teknologi informasi, harus kreatif. Materi pembelajaran diupayakan yang semua peserta didik dapat menerima dan juga tidak kesulitan dalam mengaksesnya.

Sekolah dapat memilih Learning Management System (LMS) yang sesuai dengan kondisi sekolah masing-masing dan guru yang berkomunikasi langsung dengan siswa dapat memilih konten dan media yang dapat menarik peserta didik sehingga proses pembelajaran dengan sistem e-learning bukan menjadikan beban bagi siswa tetapi merupakan pembekalan kemandirian siswa. Pada masa new normal ini semua sekolah menyiapkan pendidikan dengan sistem e- learning, demikian juga dengan Citra Bakti School. Sebagian besar para guru sudah mempersiapkan sekenario pembelajaran daring tersebut, tetapi mereka kesulitan dalam mengemas materi yang akan disajikan secara daring. Para guru juga hanya menggunakan media Sosial (Whatsapp) dan belum menggunakan media LMS. 
STKIP Citra Bakti merupakan salah satu perguruan tinggi yang berada di kabupaten Ngada yang bertujuan menghasilkan calon guru yang unggul, berbudaya dan berkarakter. STKIP Citra Bakti sangat perlu mengembangkan sayap dengan cara menyebarluaskan ilmu pengetahuan dan mengembangkan ilmu pengetahuan di era globalisasi ini guna meningkatkan pendidikan dan salah satu peran keberadaan perguruan tinggi di daerah Ngada. Peran wajib yang dijalankan oleh perguruan tinggi adalah menjalankan Tri Dharma yang harus dilaksanakan para dosen di setiap perguruan tinggi. Saat ini kita dihadapkan pada tantangan untuk meningkatkan sumber daya manusia untuk merespon kebutuhan pembangunan nasional, persaingan global, dan perkembangan teknologi dan ekonomi yang berubah dengan cepat. Pengembangan kompetensi pekerja pada tingkat pendidikan dan pelatihan adalah isu utama bagi pembangunan ekonomi yang pada gilirannya merupakan prasyarat utama untuk pengembangan masyarakat yang berkelanjutan.

Sekolah Tinggi Keguruan dan Ilmu Pendidikan Citra Bakti (STKIP Citra Bakti) dengan salah satu misinya adalah meningkatkan kepedulian sosial di tengah masyarakat dengan mengembangkan sumber daya manusia maka dari itu lembaga ini hadir untuk mengimplementasikan misi tersebut. Program kegiatan ini adalah kegiatan pendampingan bagi padar guru dimaksudkan untuk membantu para guru agar dapat menyiapkan pembelajaran daring berupa video pembelajaran yang interaktif dan menyenangkan. Kegiatan ini tentunya sangat penting dan bermanfaat serta memberikan ilmu baru bagi para guru tentang pentingnya penggunaan teknologi sebagai salah satu media yang dapat digunakan dalam meningkatkan proses pembelajaran yang berkualitas. Kegiatan pendampingan ini memiliki keunggulan yakni: guru dibekali dengan pengetahuan tentang bagaimana merancang pembelajaran daring yang interaktif (LMS) dalam bentuk video pembelajaran. Di sisi lain, para guru juga mendapatkan kesempatan secara individu untuk merancang dan mendesain pembelajarn daring dalam bentuk video pembelajaran sesuai dengan pemahaman dan teori yang didapatkan dari pemateri.

Bertolak dari uraian permasalahan di atas maka program kegiatan ini memberikan solusi bagi para guru agar mampu mendesain dan mengemas video pembelajaran interaktif dan menyenangkan bagi siswa/siswi. Tujuan kegiatan ini adalah 1) meningkatkan kompetensi guru dalam mengelola pembelajaran LMS dan 2) meningkatkan kompetensi guru dalam membuat konten pembelajaran berbentuk multimedia interaktif.

\section{METODE PELAKSANAAN}

Program kegiatan ini berjudul "Pendampingan Mengelola Pembelajaran Daring bagi Guru-guru di Citra Bakti School". Kegiatan ini akan dilaksanakan di Kampus STKIP Citra Bakti, Kecamatan Golewa. Kecamatan Golewa merupakan salah satu kecamatan yang ada di Kabupaten Ngada, Flores, propinsi Nusa Tenggara Timur. Kecamatan ini 
terletak di sebelah timur kabupaten Ngada. Secara garis besar kegiatan pelaksanaan dilakukan dalam 3 tahap yaitu Tahap Persiapan, Tahap Pelaksanaan dan Evaluasi \& Pelaporan.

Adapun kegiatan dalam proses persiapan adalah sebagai berikut :

\section{1) Analisis situasi dan kebutuhan masyarakat.}

Tahap ini dilakukan untuk menentukan kalayak sasaran dan bidang permasalahan yang akan diselesaikan. Pada tahap ini dilakukan survei ke Citra Bakti School. Disamping survey juga dilakukan wawancarakepada kepala sekolah, wakasek bidang kurikulum, dan para guru keempat unit mengenai kebutuhan para guru di sekolah khususnya berkaitan dengan kompetensi pembelajaran daring.

\section{2) Identifikasi Masalah}

Berdasarkan hasil analisis situasi dan kebutuhan dilakukan identifikasi dan perumusan masalah-masalah khusus yang dihadapi oleh kelompok sasaran. Masalah yang dihadapi para guru antara lainyakni sebagian besar para guru sudah mempersiapkan sekenario pembelajaran daring tersebut, tetapi mereka kesulitan dalam mengemas materi yang akan disajikan secara daring. Para guru juga hanya menggunakan media Sosial (Whatsapp) dan belum menggunakan media LMS.Dalamhal ini kelompok sasaran adalah guru-guru di Citra Bakti School (PAUD Terpadu Citra Bakti, SD Citra Bakti, SMP Citra Bakti dan SMA Citra Bakti).

\section{3) Menentuan Tujuan Kerja}

Pada tahap ini ditentukan kondisi baru yang akan dicapai/dihasilkan melalui kegiatan pengabdian masyarakat dengan tema Pendampingan Mengelola Pembelajaran Daring bagi Guru-guru di Citra Bakti School. Tujuan kerja yang akan dicapai dalam kegiatan ini adalah mendampingi dan membekali para guru dengan teori dan praktek mengemas dan mendesain LMS berupa video pembelajaran interaktif.

\section{4) Rencana Pemecahan Masalah}

Masalah yang sudah diidentifikasi perlu dipecahkan dan sekaligus mencapaitujuan (kondisi baru) yang telah ditetapkan. Pada tahap ini dilakukan dengan mencari alternatif pemecahan masalah dan selanjutnya memilih alternatif terbaikyang dapat dilakukan dengan memperhatikan situasi dan kondisi kelompok sasarandan pelaksana kegiatan. Pemecahan masalah yang dilakukan adalah sebagai berikut. (1) Merumuskan rancangan materi berupa teori-teori dan contoh simulasi media LMS bagi para guru. (2) keterlibatan langsung peserta dalam mengemas dan mendesain media LMS berupa video pembelajaran interaktif bagi siswa PAUD, TK, SD, SMP, dan SMA di lingkungan Citra Bakti School. 


\section{HASIL DAN PEMBAHASAN}

\section{Hasil}

Kegiatan ini dilangsungkan selama 7 (tujuh) hari sejak tanggal 20 Agsutus sampai dengan tanggal 26 Agustus 2021, bertempat di ruang Vicon STKIP Citra Bakti, Kecamatan Malanuza Kabupaten Ngada. Peserta pelatihan berjumlah 50 orang yang merupakan guru-guru Citra Bakti School, Kabupaten Ngada. Narasumber dalam kegiatan ini adalah dosen-dosen STKIP Citra Bakti Ngada program studi PG-PAUD dan PGSD Club dijabarkan sebagai berikut. (1) Dr. Dek Ngurah Laba laksana, M.Pd, (2) Konstantinus Dua Dhiu, SH., M.Pd, dan (3) Maria Desidaria Noge, M.Pd.

Kegiatan pendampingan dilaksanakan selama satu minggu sejak tanggal 20 Agsutus sampai dengan tanggal 26 Agustus 2021, bertempat di ruang Vicon STKIP Citra Bakti dimulai pukul 08.00 s.d 14.00 WITA. Dari pukul 0.00-14.00 wita, sambutan pembuka dan menyanyikan lagu Indonesia Raya oleh seluruh hadirin yang hadir dalam kegiatan tersebut. Kemudian dilanjutkan acara pembukaan berupa sambutan Ketua pengabdian kepada masyarakat STKIP Citra Bakti yang disampaikan oleh Konstaninus Dua Dhiu, SH., M.Pd sekaligus membuka acara kegiatan Pendampingan Mengelola Pembelajaran Daring bagi Guru-guru di Citra Bakti School kabupaten Ngada. Selesai acara pembukaan, dilanjutkan dengan sesi perkenalan diri oleh para pemateri kepada peserta pelatihan. Proses penyajian materi dimulai pukul 11.00 wita.

\section{Pembahasan}

Bentuk kegiatan pendampingan dilaksanakan sebagai berikut.

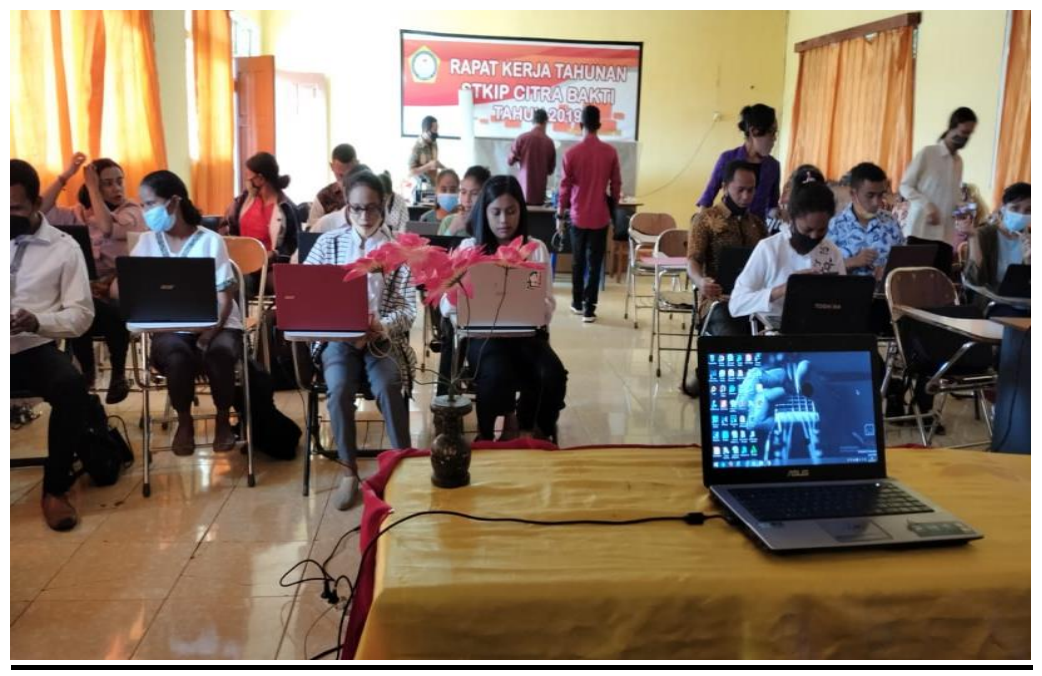

Gambar 1. Foto Persiapan Pembukaan Kegiatan 
Kegiatan diawali dengan persiapan peserta kegiatan dan kegiatan pembukaan oleh panitia.

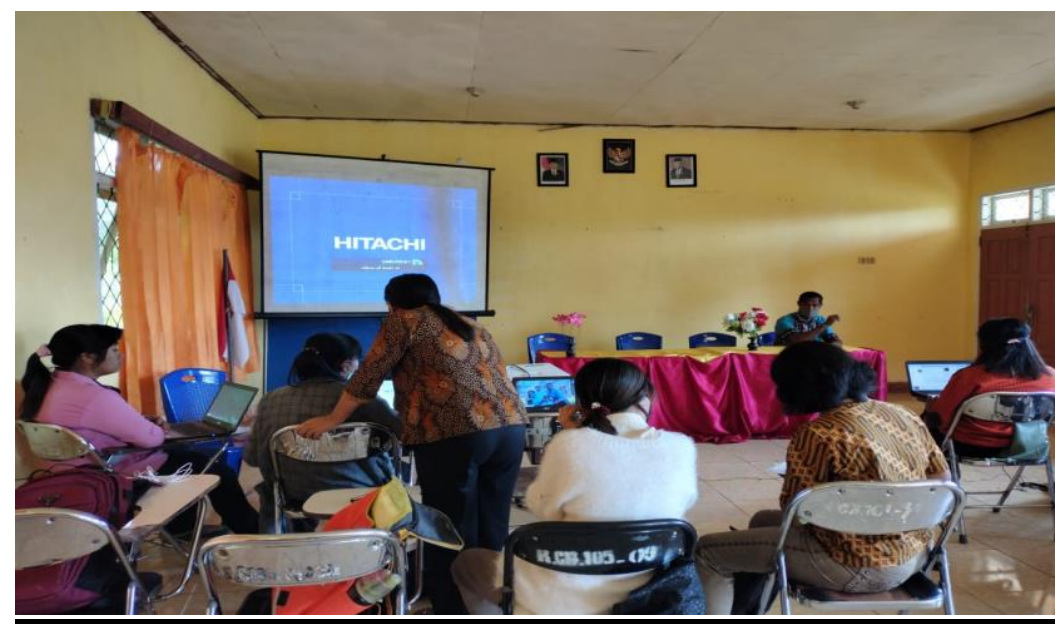

Gambar 2. Foto Arahan Alur Kegiatan

Dilanjutkan dengan arahan alur kegiatan oleh ketua pengabdian yakni bapak Konstantinus Dua Dhiu, SH., M.Pd yakni menjelaskan gambaran alur kegiatan yang akan dilalui selama 1 minggu.

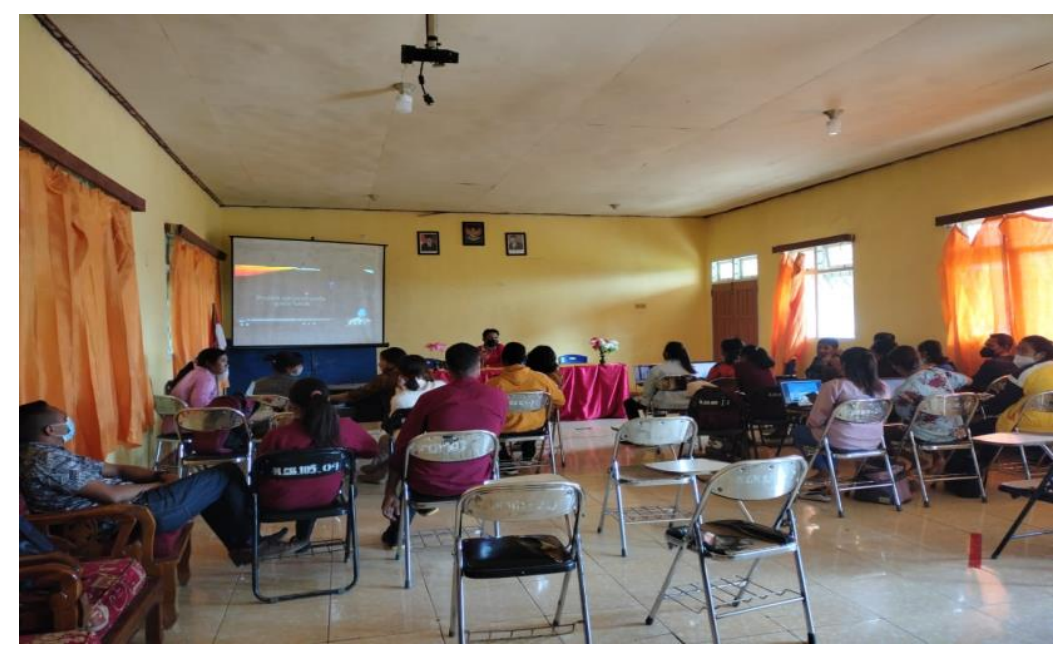

Gambar 3. Foto Kegiatan Pelatihan

Berikutnya penyajian materi oleh narasumber selama 3 hari dan diikuti oleh seluruh peserta kegiatan. Dalam sesi ini, diselipkan sesi Tanya jawab apabila peserta mengalami kesulitan dan ingin memberikan pertanyaan kepada narasumber. 


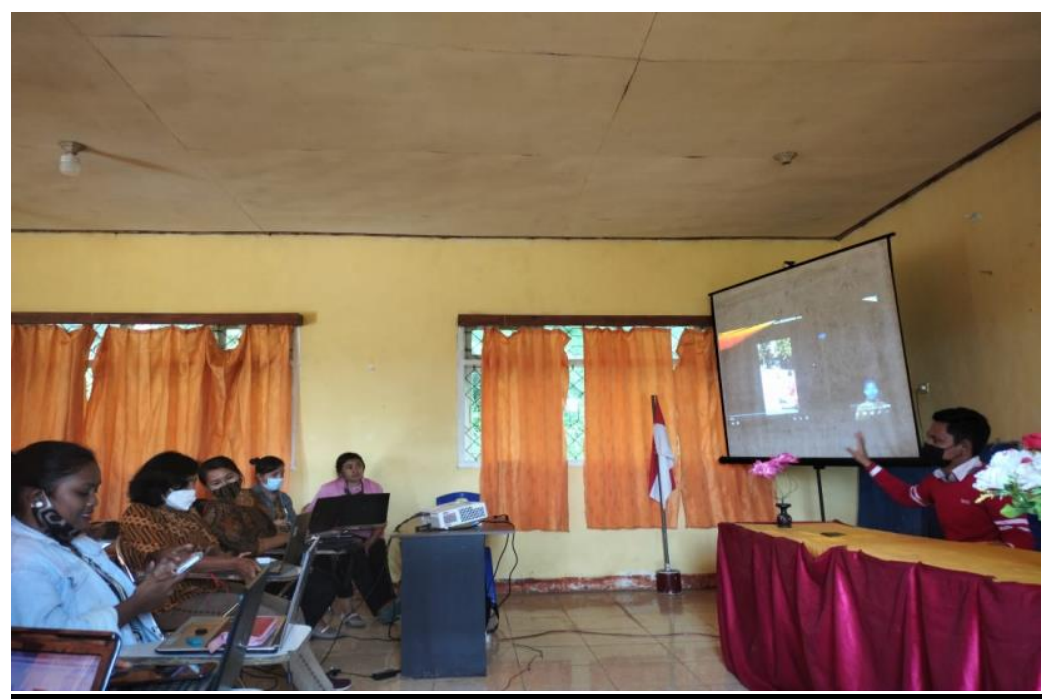

Gambar 4. Foto Simulasi Kegiatan

Di hari keempat dilanjutkan dengan sesi simulasi singkat oleh narasumber di mana dijabarkan dan ditayangkan contoh video pembelajaran interaktif yang dapat digunakan dalam proses pembelajaran.

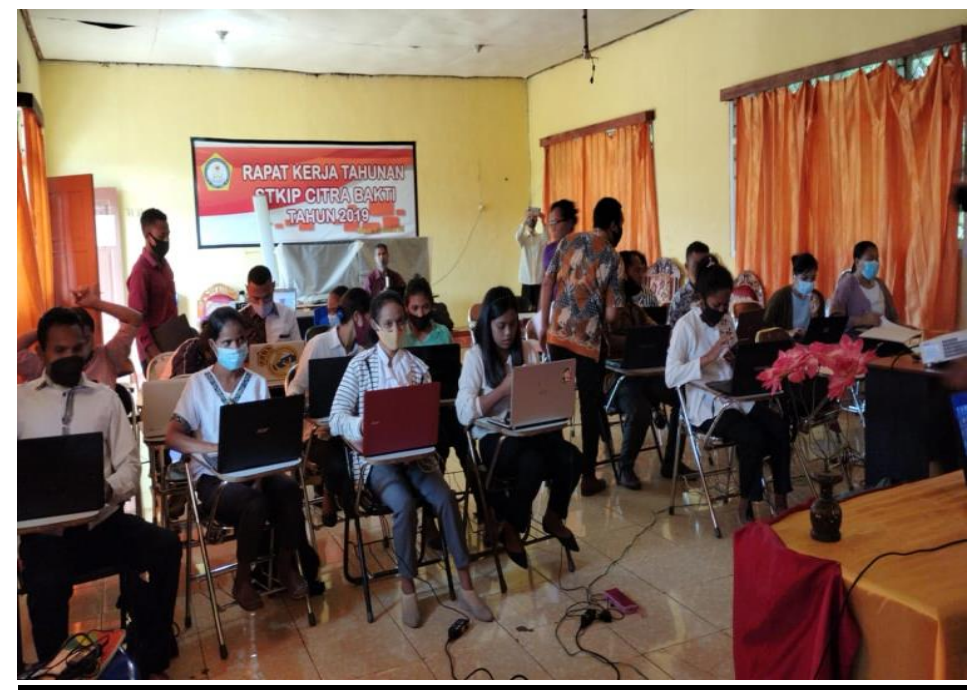

Gambar 5. Foto Kegiatan Pembimbingan Individu

Selanjutnya pada hari kelima dan keenam dilaksanakan kegiatan praktek yakni pembimbingan secara individu untuk mendesain video pembelajaran interaktif oleh masing-masing guru. Dalam sesi ini, guru-guru didampingi oleh para narasumber untuk menghasilkan produk LMS yang baik dan berkualitas.

Di hari ketujuh, kegiatan pendampingan yang dilakukan adalah presentasi video pembelajaran oleh masing-masing guru untuk mengetahui hasil dan kualitas dari video pembelajaran interaktif yang telah dihasilkan. Lalu dilanjutkan dengan penguatan materi oleh para narasumber dan pemberian penghargaan bagi karya- 
karya yang telah dihasilkan para guru. Kegiatan pendampingan ini diakhiri dengan acara penutupan oleh panitia dan ditutup dengan sesi foto bersama narasumber dan peserta.

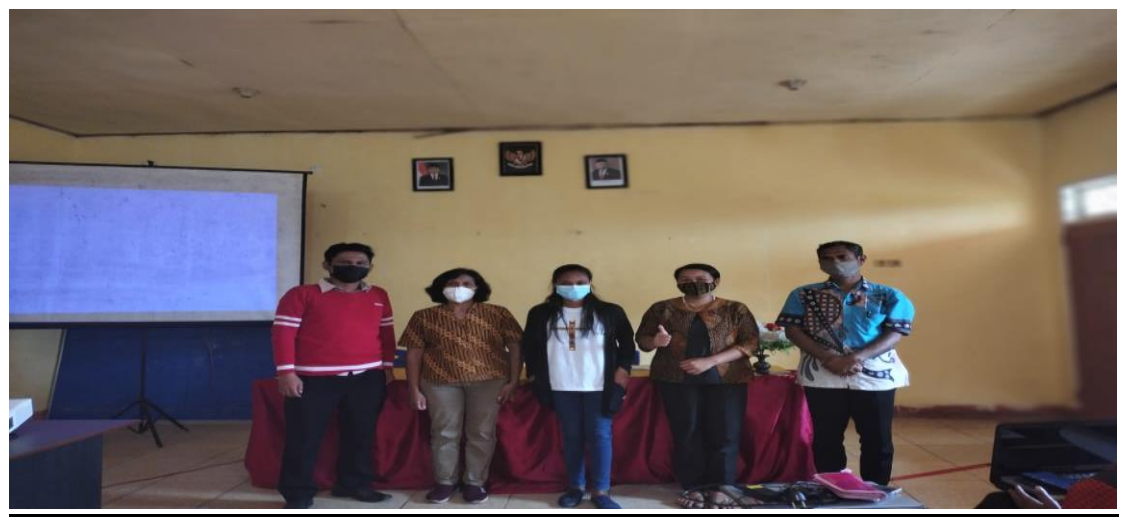

Gambar 6. Foto Bersama Unit PAUD Terpadu Citra Bakti

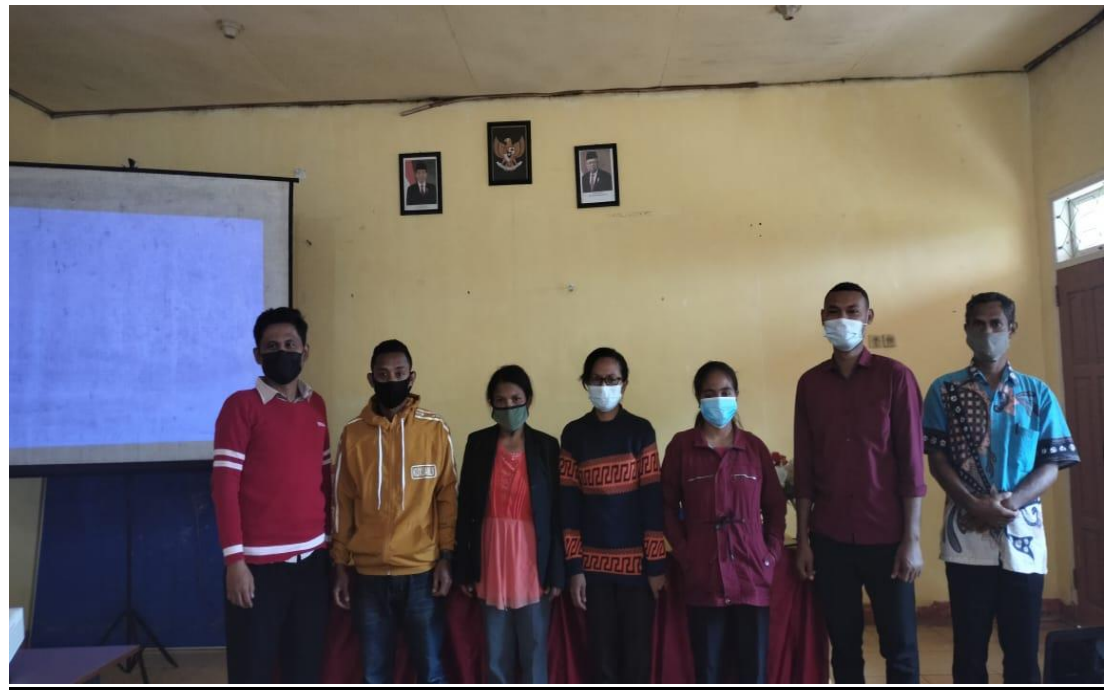

Gambar 7. Foto Bersama Unit SD Citra Bakti

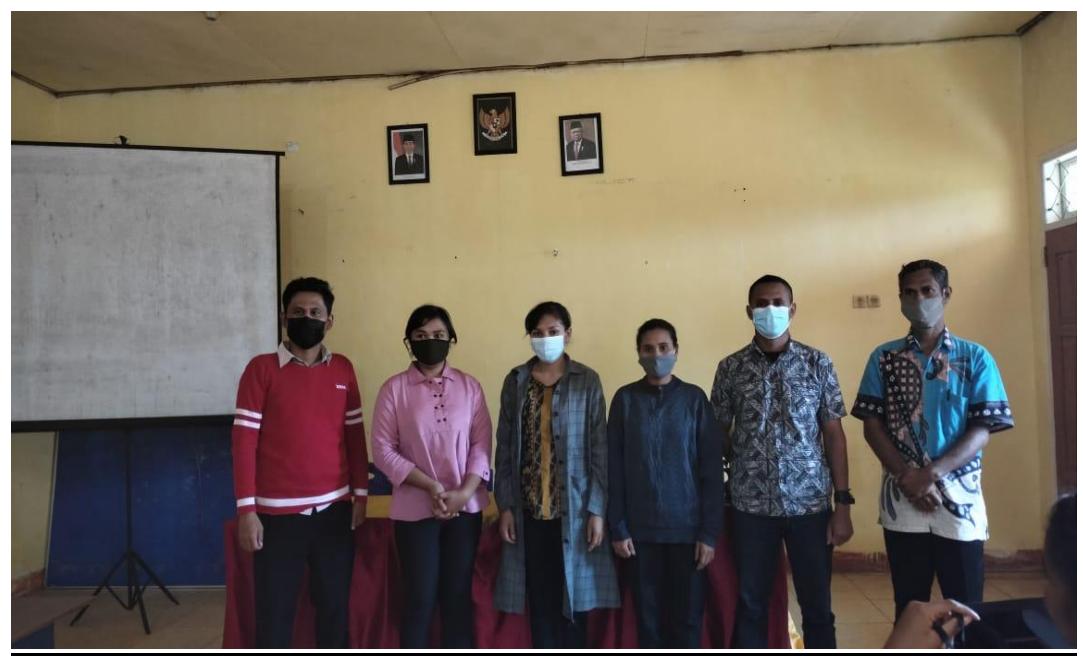

Gambar 8. Foto Bersama Unit SMP Citra Bakti 


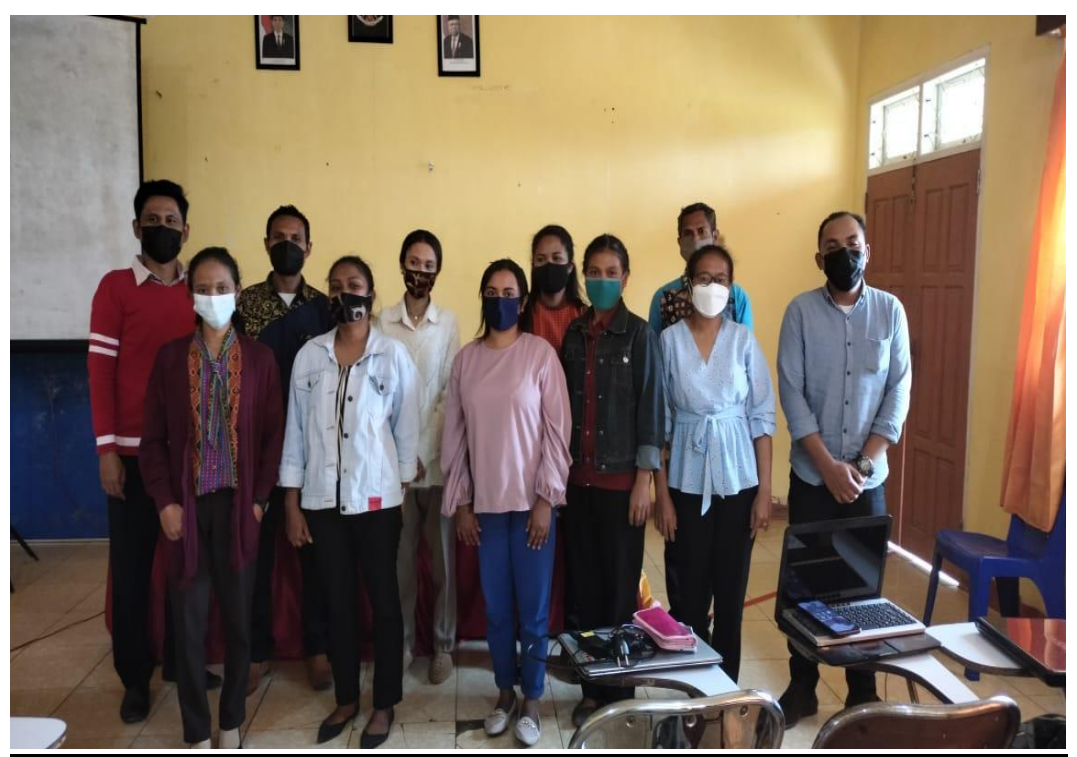

Gambar 9. Foto Bersama Unit SMA Citra Bakti

Setelah dilakukan program kegiatan pengabdian ini dan dilakukan evaluasi dan rencana tindak lanjut terhadap proses dan hasil, maka diperoleh hasil sebagai berikut.

1) Pelatihan Pembuatan Video Pembelajaran telah selesai dan lancar dilaksanakandengan diikuti oleh seluruh Guru di Citra Bakti School.

2) Guru-guru sudah mampu menghasilkan video pembelajaran interaktif namun masih membutuhkan pendampingan lebih lanjut oleh para narasumber.

3) Selanjutnya dilakukan pendampingan pelaksanaan pembelajaran daring yang didampingi dosen sebagai narasumber selama 2 bulan.

4) Sebagai tindak lanjut dari kegiatan ini adalah dilakukannya perlombaaan pembuatan video pembelajaran oleh para guru. Masing-masing unit mengutus 2 orang peserta untuk membuat video pembelajaran yang kemudian video tersebut dinilai oleh para dosen.

5) Kegairahan guru dalam mengikuti kegiatan dan membuat video pembelajaran sangat baik yang ditandai dengan antusiasme para guru.

\section{KESIMPULAN}

Kesimpulan yang dapat diambil dari kegiatan pendampingan ini adalah sebagai berikut. (1) Penguasaan kompetensi guru dalam mengelola pembelajaran daring bagi guruguru Citra Bakti School dilakukan dengan strategi antara lain: penyamaan persepsi kebutuhan pembelajaran daring, pemilihan LMS yang sesuai dengan karakter Sekolah, Guru, dan Peserta Didik, pendampingan intensif dalam praktek langsung pelaksanaan pembuatan video pembelajaran, pembuatan materi pembelajaran dalam bentuk media interaktif telah 
dilakukan dengan memanfaatkan media sosial yang familiar dengan peserta didik, penggunaan media memberikan gairah dalam aktifitas mengajar guru dan aktifitas belajar peserta didik, Perlu adanya komitmen dari institusi (Citra Bakti School) dan lembaga STKIP Citra Bakti untuk memberikan penguatan dan menjaga konsistensi motivasi para guru dan peserta didik, dan para guru perlu bereksplorasi dan berinovasi dalam strategi pembelajaran untuk membuat kegairahan belajar siswa terjaga dan meningkat.

\section{DAFTAR PUSTAKA}

Astini, N. K. (2020). Tantangan dan Peluang Pemanfaatan Teknologi Informasi dalam Pembelajaran Online Masa Covid-19. Jurnal IImu Pendidikan, 3(2), 241- 255

Firman, (2020). Pembelajaran Online Ditengah Pandemic Covid-19. Indonesian Journal of Educational Science Volume 02, No 02 Maret 2020, 82

Istyarini, dkk. (2021). Program Pendampingan Guru-Guru Dalam Menyelenggarakan Pembelajaran Daring. Available at https://journal.unnes.ac.id/sju/index.php/puruhital (diakses pada tanggal 28 Oktober 2021)

Junita Rofika., Dini, F (2020), Efektivitas Penggunaan Aplikasi Zoom Sebagai Media Pembelajaran Online Pada Mahasiswa Saat Pandemi Covid-19. Jurnal Communio : Jurnal IImu Komunikasi, Volume IX, No. 2, Juli-Desember 2020, hlm 1630 - 1640

Lawe, Y.U., dkk. 2020. Pendampingan Guru SD dalam Penyelenggaraan Olimpiade MIPA Tingkat SD. Jurnal Abdimas IImiah Citra Bakti. Vol.1. No. 2. Diakses dari https://jurnalilmiahcitrabakti.ac.id/jil/index.php/jailcb/article/view/75/80 pada 9 September 2021

Pancawati, MB.D. 2020. Suka Duka Belajar Di Rumah. Artikel Kolom Bebas Harian Kompas Online Diakses dari https://bebas.kompas.id/baca/riset/2021/03/26/suka-duka-belajardi-rumah/ pada 30 Agustus 2021.

Surat Edaran Kemendikbud Nomor 2 Tahun 2020 tentang Pencegahan dan Penanganan Covid-19 di lingkungan Kemendikbud. Diunduh dari https://jdih.kemdikbud.go.id/arsip/SE\%20Nomor\%202\%20Tahun\%202020\%20 tentang\%20Pencegahan\%20dan\%20Penanganan\%20Corona\%20di\%20Kemendikbu d.pdf tanggal 30 Agustus 2021.

Surat Edaran Kemendikbud Nomor 3 Tahun 2020 tentang Pencegahan Covid-19 pada Satuan Pendidikan. Diunduh dari https://jdih.kemdikbud.go.id/arsip/SE\%20Nomor\%203\%20Tahun\%20

2020\%20tentang\%20Pencegahan\%20Corona\%20pada\%20satuan\%20pendidikan.pd f tanggal 30 Agustus 2021.

Unik, H.S. (2020). Pemanfaatan Teknologi Media Pembelajaran di Masa Pandemi Covid-19. Jurnal Pendidikan Dasar. Vol.2 No.2 Desember 2020. p-ISSN 2685-7642 / e-ISSN 2685-8207

Veronika A. S, Yustinus B. H. (2021), Online Learning During the Covid-19 Pandemic (Study at Several Schools and University in Indonesia). Jurnal Pendidikan dan Pengajaran, Vol.54, No.1, e-ISSN: 2549-2608 